\title{
30
}

\section{WASTE LEGISLATION APPROXIMATION TO EU DIRECTIVES IN ESTONIA}

Matti Viisimaa

Reigo Lehtla

Waste Division of Ministry of Environment

Estonia

\section{DESCRIPTION OF THE WASTE SECTOR}

The annual waste production is registered according to Estonian Waste Classification system. The enterprises (for industrial waste) and the municipalities or municipal enterprises (for municipal waste) are obliged to declare annually the quantity of waste generated, treated, disposed, recovered, imported and exported.

\section{Organisation and Institutional review}

Present system was established in 1991-1993. Responsibilities for waste management and remedial programmes are shared among the ministries of the environment, economics and agriculture, counties and municipal authorities.

The Ministry of the Environment is responsible for formulating the national waste policy, budgeting of the local waste management plans, establishing institutions responsible for the construction of hazardous waste treatment facilities and issuing licenses for these facilities and for the control of trans-boundary movements of waste. The tasks are executed by the Waste Division, which also has the responsibility of drafting the legislation and strategies in relation to the approximation with EC waste legislation. The waste division has a staff of 4 technical employees (experts). 
The Ministry of the Environment have established the following institutions:

- the Waste Management Commission to implement the Basel Convention for the controlling of the hazardous waste generation, treatment and international movement through a permitting system

- the Hazardous Waste Management System Unit for the project management and co-ordination of the implementation of the hazardous waste management system This Unit is co-ordinating all the activities related to the designs and construction for the collection, management and disposal sites for hazardous waste included in the future system for hazardous waste management.

- the Environmental Information Centre for establishing national waste surveys and collection of information an waste.

The Chief Inspectors Office (the Environmental and Nature Protection Inspectorate) is responsible for the enforcement of environmental legislation. However, many of the day-to-day enforcement tasks are delegated to the County Environmental Departments.

The organisation of Estonian Ministry of the Environment is shown in Annex 10.

The County Environmental Departments, which are a part of the County Government, are responsible for issuing waste permits and supervision and control of their implementation. They collect data at local level for transmission to the Ministry of the Environment.

They also collect waste charges.

Normally the counties have only one waste officer, who is also responsible and occupied with other areas within environmental protection e.g. air pollution.

At local level, the producer is responsible for its waste up until delivery to a waste management company. The municipalities are responsible for organising domestic waste collection and treatment. Towns and municipalities manage their own waste (collection, transport and disposal of household waste), the waste planning programme of their locality, and decide on the siting of waste disposal facilities. They are also responsible for providing collection points for hazardous waste, and ensuring their subsequent transport to controlled transfer stations (or sites).

Towns and large municipalities may have 1 technical employee within solid waste management, while small rural municipalities normally have only one technician dealing with all environmental and technical issues within the municipality. 


\section{Information streams}

1. The waste data are forwarded to the Statistics Department of Estonia and the Environmental Information Centre, which are responsible for collection of all data in a specific data base, preparation of an overview of the annual waste generation and of operation a register of all relevant industrial waste producing and treating enterprises. The county environmental authorities collect and control these declarations and send them to the SDE and the EIC.

2. The Statistics Department of Estonia forward questionnaires (sheets of declaration) through the Ministry of the Environment and the County Environmental Departments to all relevant companies to ensure a sufficient overview of the annual waste generation.

These main companies directly asked are:

- all companies with a waste permit;

- all companies in the chemical sector (and further selected sectors);

- all municipalities or municipal waste management enterprises.

3. The Environmental Information Centre collects all data in a specific data base and prepares an annual overview of the waste generation. The data base contains a register of all relevant industrial waste producing and treating enterprises. Combined with the data base of waste generation, a listing of waste producing companies, organised according quantity or quality criteria (hazardousness etc.), could be prepared.

\section{Waste streams}

Many of the existing serious environmental problems in Estonia are connected with solid waste, especially with hazardous waste generation and their disposal. The seriousness of the waste problems can be demonstrated by the huge amounts of waste disposed every year. In 1996 more than 14 million tons of waste were generated in Estonia (about 9 tons per capita). The main part of this amount, some 7.3 million tonnes, can be characterised as hazardous waste according to the Estonian Waste Classifier, which introduces four classes of hazardous waste according to their hazardousness.

According to the Estonian Waste Classifier, most of the waste generated in oil shale energy and chemical production is considered hazardous, mainly due to its high alkalinity. The amount of inert mining residues produced in 1996 was 5.5 million tonnes. The waste from other industrial and agricultural activities formed only $2.3 \%$ and $2.9 \%$ respectively from the total amount.

The volume of the hazardous waste in class II is mainly due to the waste generated during oil-shale chemical processing (approximately 75\%). The hazardous waste in class It is mainly generated from residue of pesticides and waste from mercury bulbs. The amount of waste stored in landfills, lagoons, dumps is estimated at more than 440 million tons. 
According to the Estonian Waste Act and Estonian Waste Classifier hazardous wastes are divided into four classes of hazardousness according to their harmful effects. The total generation of waste of each class in $1994-1996$ is shown in the following table:

Table 1: Waste generation in Estonia in 1994-1996 (in tonnes)

\begin{tabular}{|l|r|r|r|}
\hline Hazardousness & $\mathbf{1 9 9 4 , \mathbf { t }}$ & $\mathbf{1 9 9 5 , \mathbf { t }}$ & \multicolumn{1}{|c|}{$\mathbf{1 9 9 6 , \mathbf { t }}$} \\
\hline I (extremely hazardous) & 33 & 78 & 44 \\
II (highly hazardous) & 10126 & 11837 & 9988 \\
III (moderately hazardous) & 1508822 & 145246 & 1531796 \\
IV (slightly hazardous) & 5956595 & 5808963 & 6137042 \\
\hline Total waste & $\mathbf{1 3 8 1 8 3 1 7}$ & $\mathbf{1 3 4 0 5 9 7 3}$ & $\mathbf{1 4 6 8 6 7 2 4}$ \\
\hline
\end{tabular}

Table 2: The main waste types generated in Estonia

\begin{tabular}{|c|c|c|c|c|}
\hline Groups of Waste & $\begin{array}{l}\text { dimension } \\
\text { measured }\end{array}$ & 1994 & 1995 & 1996 \\
\hline $\begin{array}{l}\text { Household Waste, light office and light } \\
\text { commercial waste }\end{array}$ & mil t & 0.473 & 0.533 & 0.564 \\
\hline $\begin{array}{l}\text { Urban Sewage Sludge (average share of dry } \\
\text { matter \%) }\end{array}$ & mil $t$ & 0.217 & 0.411 & 0.456 \\
\hline industrial waste & mil t & 13.162 & 12.367 & 13.393 \\
\hline $\begin{array}{l}\text { Non Hazardous Industrial Waste (including } \\
\% \text { of construction waste) }\end{array}$ & mil $\mathrm{t}$ & & $\begin{array}{c}5.380 \\
(3.93 \%)\end{array}$ & $\begin{array}{c}6.121 \\
(6.15 \%)\end{array}$ \\
\hline $\begin{array}{l}\text { Hazardous Industrial Waste, } \\
\text { including }\end{array}$ & mil t & & 6.987 & 7.273 \\
\hline oil, oily waters and sludge & & 20.82 & 16.30 & 11.86 \\
\hline $\begin{array}{l}\text { solvents, glues, paints, varnishes } \\
\text { and other high caloric hazardous waste }\end{array}$ & thous.t & 0.92 & 1.82 & 4.19 \\
\hline $\begin{array}{l}\text { sludge from biological waste water } \\
\text { treatment in industry }\end{array}$ & $\begin{array}{l}\text { not } \\
\text { registered }\end{array}$ & & & \\
\hline $\begin{array}{l}\text { slag, ash and dust from combustion } \\
\text { processes or smelters }\end{array}$ & $\operatorname{mln} \cdot t$ & 7.266 & 6.947 & 6.444 \\
\hline $\begin{array}{l}\text { galvanic sludge, metal concentrates or acid } \\
\text { from electroplating and metal processing }\end{array}$ & $\mathrm{t}$ & 54 & 45 & 44 \\
\hline others & & & & \\
\hline
\end{tabular}


Industrial waste includes: construction waste, waste from energy production, mining waste, oil-shale and other processing and production waste

\section{Municipal Waste Management}

The generation of municipal solid waste in 1995 was 553,400 tonnes or 335 kg per capita.

Almost all the municipal solid waste is disposed of at dumpsites without separation. There are no facilities for incineration and composting of domestic waste in Estonia, and practically no waste has been separated, incinerated or composted. A separate collection system for specific types of waste such as paper, cardboard, batteries and glass are at present in an early stage of developmente

Most of the dumpsites in Estonia have been located and established without any geological-hydrogeological investigations. Areas not used by agriculture or forestry (old open pits, edges of mashes etc.) have mostly been used. As most of the dumpsites cover small areas and are located far from residential areas, no noticeable pollution of surface water and groundwater has been observed. Complaints concerning water pollution and smoke from burning from large dumpsites located in the vicinity of larger towns have been received. In the Tallinn dumpsite, the landfill gas is collected and used in two boilers for heating dwelling houses.

At present there are $\mathbf{5 2 3}$ registered dumpsites in Estonia, incl. 348 solid domestic waste dumpsites of which 273 are in use, 47 have been closed down, 21 have been finalised and 8 are currently under construction.

The strategically goal is to reduce the number of municipal landfill sites to 20-30 and to development the sites in accordance with EC requirements on environmental and health safety. The goal is also to stabilise waste for landfilling on a level of $250-300 \mathrm{~kg}$ per capita per year.

The medium-term priorities are to reduce the number of municipal landfill sites to 120 - 150 and to dispose at least $40 \%$ of waste in accordance with internationally accepted requirements for environmental and health safety, to establish control conceming the quality and quantity of the disposed waste and to stop illegal waste dumping.

\section{Hazardous Waste Management}

The present treatment of hazardous waste is limited to some special waste types such as mercury lamps, lead batteries and bilge oils from ships for which specific facilities exist including one minor facility for incineration of oil waste.

In Tallinn the collection of accumulators, batteries and other hazardous waste generated in domestic condition is based on fuel stations. Some counties have established their own collection system for batteries and deliver the batteries to a company in Tallinn. The batteries are exported to England, Spain or Sweden.

Several companies are dealing with treatment of hazardous waste collection, separation and transportation, oil and fuel treatment, treatment of bilge water, mer- 
cury bulb treatment, lead accumulator collection and treatment; treatment of organic poisons and composting of oil-shale waste.

However, the capacity available for treatment of most categories of hazardous waste is insufficient. Therefore the establishment of a national hazardous waste management system with waste collection points, transfer and reloading stations, disposal and treatment facilities has been initiated by Estonian Ministry of the Environment with the support of the Danish Government and the EU PHARE Cross Boarder Co-operation Programme. The overall target is to secure the treatment and disposal of the most hazardous waste generated within Estonia in an environmental sound manner by the year 2000 .

Implementation of the National Programme for the Hazardous Waste Management System has started, and the construction of facilities for a transfer station for hazardous waste in Tallinn have been completed. The problem is the final treatment of hazardous waste. It was expected that the establishment of a landfill for hazardous waste and a transfer station in the Sillamäe area will start at the end of 1997.

Facilities for thermal treatment of hazardous waste is planned established in a power plant or in a cement plant, but the final solution has not yet been selected for all categories of hazardous waste. In general the selection of facility and location for incineration of hazardous waste has caused problems.

\section{Waste Recycling}

At present, paper for recycling and glass waste is collected. There are not many companies dealing with waste recycling. One of the reasons may be the gaps in the relevant legislatione The companies have no economical interest in using waste as a raw material.

A project, for which the Institute of Chemistry and the Estonian Power Plant are the main initiators, of utilisation of rubber waste by thermal treatment together with oil-shale is planned. A project concerning glass waste treatment in Järvakandi is also foreseen.

Due to lack of facilities for treatment and disposal of some recyclable categories of waste, the export of waste from Estonia in 1995 included 264,000 tonnes of scrap metal and waste (among this 2,094 tonnes of exhausted lead batteries), 5,065 tonnes of paper and cardboard waste, 238 tonnes of plastics and 47,100 tonnes of oil-shale fly-ash.

The Estonian Ministry of the Environment assumed that, after the Packaging Act of 26 May 1995 and the Packaging Excise Act of 01 March 1997 came into force, the situation in the field of waste recycling could rapidly change as an economic interest in recycling of package waste has been stimulated by companies. 


\section{NATIONAL LEGISLATION ON WASTE SECTOR}

The legislative framework in the field of the waste management is based on the Waste Act ( 1992, as amended in 1994 and revised recently in full extent in 1997), the Act on Protection of Estonian Nature (1990) and the Act on Sustainable Development (1995). In these acts the principles of waste prevention, minimisation and source reduction are determined. Waste Act defines the waste and its main categories (municipal waste and waste of productional origin incl. industrial, agricultural, mining and quarrying waste; hazardous and inert or nonhazardous waste; secondary raw materials and discharges). Hazardous waste management is also included in the Waste Act.

The Estonian Waste Act is complemented by several lower level regulative acts issued as regulations of the Government or of the Ministry of the Environment, including the following:

- Estonian Waste Classifier (1991)

- On Issuing of Licences for Handling of Hazardous Waste (1992)

- On Issuing of Waste Permits (1992)

- On Labelling of Hazardous Waste

- On Export, Import and Transit Movements of Hazardous and Other Waste.

Estonia ratified the Basel Convention in 1992. The main principles of the Convention and the notification procedure were incorporated into national legislation with Government Statute on Export, Import and Transit Movements of Hazardous and Other Waste (1992).

To enable co-operation between the Baltic States, and in particular Lithuania which is at present not a member of Basel Convention - in the field of hazardous waste management, the Estonian Ministry of the Environment has signed a special agreement with the Lithuanian Ministry of Environmental Protection on the control of transboundary movements of hazardous waste between the two countries

At present there are no special legal acts on landfills, but common requirements for reducing the risk of soil and groundwater pollution are laid down by Waste Act and other environmental acts. The regulation on the landfilling requirements of waste is on harmonisation stage right now.

The sludge from urban wastewater treatment is considered a category of municipal waste, but the regulation of its use in agriculture and for soil improvement (Regulation of the Ministry of the Environment on Limitation of Use of the Fertiliser and Sewage Sludge, 1994) is based on the Water Act (1994, as amended 1996).

The Packaging Act (1995) provides a basis for dealing with the increasing quantities of packaging waste, encouraging prevention, reduction and recovery of this waste category. An amendment on the Packaging Act has been approved by 
Riigikogu on 30 June 1997 and pronounced by the President on 7 July 1997. The Packaging Act is supported by The Packaging Excise Act.

At present there are no specific legal acts concerning incineration of municipal or hazardous waste. The levels of emission from the waste incineration units are regulated by the conventional air pollution regulation documents.

\section{APPROXIMATION OF THE WASTE LEGISLATION}

Ten countries in Central and Eastern Europe (CEE) have signed association agreements - Europe Agreements - with the European Union (EU). Estonia signed the association agreement in 1995. Under the Europe Agreements, the associated countries commit themselves to approximate their legislation to that of the EU. The agreements provides for financial assistance including grant assistance, from the EU to the associated countries.

\section{White Paper}

The EU's Pre-Accession Strategy defines a number of tools and measures to be employed in the pre-accession phase, including the White Paper on the Preparation of the Associated Countries of Central and Eastern Europe for Integration into the Internal Market of the Union. The White Paper gives specific guidelines for the preparation of the CEE countries for the integration into the internal market of the EU. However, most of the environmental legislation is not covered by the White Paper, but EU has emphasised to the associated countries that membership of the EU is dependent upon adoption of the whole "acquis communautaire" and not just the directives identified in the White Paper.

At present, the Estonian Government is emphasising approximation of the White Paper legislation, and aims to introduce the White Paper legislation into the Estonian legislation by the end of 1997. Furthermore, the Government has requested that the Estonian Ministry of the Environment presents a strategy for approximation of the remaining EC environmental legislation by the end of 1997.

The Estonian Government has made a strong commitment to approximate all its legislation with the EC requirements, and it's goal is to introduce the White Paper legislation, including waste management directives as well as the EC requirements for landfills, into Estonian legislation by the end of 1997. Specific requirements e.g. more stringent requirements for specific waste streams, limit values, targets, inventories etc. as well as the establishment of an administrative infrastructure and adoption of necessary institutions and structures should be implemented within the next five years along with the EC waste legislation not included in the White Paper

At present a new version of the Estonian Waste Act has been prepared at the Ministry of the Environment which takes into consideration the definitions, main/general principles and specific requirements of the framework directives on waste (75/442/EEC) and hazardous waste (91/689/EEC). In new version of Waste Act the basic definitions used in EU directives, incl. definitions of waste and 
hazardous waste, will be directly included in Estonian legislation. The new Estonian Waste Act is on the harmonisation stage right now and will adopted by the Parliament in the next year.

The European Waste Catalogue (94/3/EC) and list of hazardous wastes (94/904/EEC) are already approved with the Decree of Estonian Government in August, 1997. As first step of implementation of EU classification system these lists have only informative use at the transboundary movements of wastes and for exchange of information with EU and other countries. Next year when the new Waste Act will be adopted, the completed with Estonian specific waste categories lists would also serve as basis for waste and hazardous waste definitions.

\section{Amendments and Gaps in legislation}

In recent years, Estonia has been remarkably successful in developing environmental legislation, particularly in the waste sector.

Danish EPA experts have concluded in summer, 1996 (after the implementation of gap analysis of the Estonian Waste legislation) that:

- the extent to which Estonian waste legislation has been adopted - the objectives of Estonian waste legislation are in line with the framework directives, the shipment regulation

- the Estonian legislation, to a large extent, addresses the same issues as the EC legislation

However, the comparative analysis on the implementation of EC legislation into Estonian Law has revealed a number of significant gaps and areas of differences

Thus, it was concluded that approximation requires:

- full revision of the Estonian Waste Act - taking into consideration the definitions, main/general principles and specific requirements of the framework directive on waste, the hazardous waste directive, waste oil-, PCB-, and battery directives.

- minor revisions of the Packaging Act.

- development of supplementary legislation to the Packaging Act implementing the Commissions decision on formats for databases and identification systems

- development of new Estonian legislation for landfills based on the definitions, main/general principles and specific requirements of the proposal/adopted directive on landfilling of waste

- full revision of the Estonian Sewage Sludge Act - taking into consideration the definitions, main/general principles and specific requirements of the sewage sludge directive

- development of new Estonian legislation for incineration of municipal and hazardous waste based on the definitions, main/general principles and specific requirements of the Directive on Prevention of Air Pollution from new Municipal Incineration Plants, Directive on the Reduction of Air Pollution from 
Existing Municipal Waste Incineration Plants and on the Directive on Incineration of Hazardous Waste.

Considering the large number of environmental laws that have been adopted since 1990, and the framework of many of them, one of the main concerns, apart from the adoption/revision of the legislation mentioned above, it was estimated, that Estonian Government and the Ministry of the Environment are able to implement these improvements. But there occurs number of problems associated with the lack of follow-up regulations and governmental capacity (at both national and district/regional level) to monitor compliance. The framework laws are rarely supported by adequate regulations governing their implementation, due to lack of time and/or manpower.

Specific requirements e.g. more stringent requirements for specific waste streams, limit values, targets, inventories etc. as well as the establishment of an administrative infrastructure and adoption of necessary institutions and structures should be implemented within the next five years along with the EC waste legislation not included in the White Paper

The physical implementation (network of treatment facilities etc.) will be carried out currently over a longer period depending on the economical ability of Estonia. Thus - the main challenge facing Estonia in implementing EC legislation, does not lie in the approximation of the legal texts, but in adapting the administrative machinery and societies to the conditions necessary to make the legislation worke

Insufficient enforcement and monitoring of some of the existing legislation has been identified as a major problem, and the need of institutional strengthening and capacity building at all level is obvious. It is strongly recommended that high priority be given to capacity building and training of the staff at all levels regarding the practical implementation, administration and enforcement of the legislation.

\section{Estonian Strategy}

The main principles of the Estonian Waste Management Strategy have been formulated in the Waste Act (14.11.92 amended 12.10.94) and the National Environmental Strategy, which has been approved by the Parliament on 12 March, 1997.

The National Environmental Strategy sets up the following goals on the reduction of waste generation and improvement of waste management:

- To support sustainable use of raw materials

- To reduce waste generation

- To stimulate waste recycling

- To reduce environmental pollution caused by waste

- To reduce areas, contaminated by waste

- To improve waste management (especially hazardous waste management) 
As general objectives of the waste management strategy, the National Environmental Strategy, Estonia states that the choice of solutions for improving the waste management system should be based on the following list of priorities:

1. Prevention of waste generation

2. Reduction of generated waste volumes and decrease in their hazardousness

3. Reduction in the quantity and scale of recycled wastes:

- reuse of waste

- recycling of waste

- use of biological processes (composting)

- energy production (combustion)

4. Consideration of environmental safety and requirements in waste treatment

5. Environmentally safe disposal and final disposal of waste

Furthermore, the general objectives include the rational use of natural resources, responsibility of the waste generators and owners of the waste and implementation of the "polluter pays" principle in the field of waste management.

The tasks by the year 2000 are as follows:

- To stabilise waste generation in industry and in households at the 1995 level

- To appoint owners/operators for existing landfills and to close down landfills which do not have an owner/operator

- To increase the degree of waste recycling to $30 \%-40 \%$

- To establish new landfills and close down old disposal sites in accordance with the requirements of the European Union

- To dispose $40 \%$ of municipal waste in accordance with environmental and health protection requirements

- To introduce a hazardous waste management system

- To develop a programme for radioactive waste treatment and to ensure environmental safety of the existing disposal sites

- To achieve compliance monitoring concerning all waste generators

The tasks by the year 2010 are as follows:

- To improve disposal methods and the use of oil-shale processing waste

- To increase the share of waste recycling to $50 \%$

- To stabilise municipal waste generation at an annual level of $250-300 \mathrm{~kg}$ per person

- To optimise the number of municipal landfill sites (up to 150)

- To treat, dispose and dump all wastes according to internationally accepted environmental and health protection requirements

- To reduce the share of hazardous waste in the total waste volume

- To construct a radioactive waste storage facility that meets European Union requirements

- To offer waste management services all over Estonia 
In the area of waste services, the goal is to extend and improve waste collection and transportation systems. Privatisation processes in Estonia are having an impact on this field of activity. Privatisation should promote the application of the Polluter Pays Principle in waste management via the establishment of service charge rates which would ensure that generators of waste cover the full cost of their disposal in an environmental safe manner.

\section{Projects, running on Approximation}

The most important multilateral donor has been the EU PHARE Programme, which has initiated several environmental projects. With respect to bilateral donors, the Danish Government started to assist Estonia with environmental protection projects even before Estonia regained independence. The Finnish Government, which is the most important bilateral donor within environmental protection projects, has also funded some projects in the field of waste management.

Based on the feasibility study on hazardous waste management, the Estonian Ministry of the Environment initiated the establishment of a national hazardous waste management system with support from the Danish Government and the EU PHARE Cross Border Co-operation Programme. The physical implementation of the system have been initiated.

Other relevant projects:

- PHARE-project on Estonian Approximation Strategy (DISAE - Development of the Phare programme of Implementation Strategies for Approximation in Environment):

The project will commence within a short time and will be completed by the end of 1997. The specific objective of the project is to assist the Estonian Ministry of the Environment in developing an effective approximation strategy in order to meet the requirements of EC environmental legislation. The project will include an overview of the status of environmental approximation in Estonia, a legislative gap analysis including a comparative analysis, an implementation analysis, an investment analysis and development of strategic options related to the phasing of environmental approximation.

- PHARE-project on National Environmental Action Plan, Estonia:

The objective of the project is to improve environmental planning and management in Estonia through the adoption of a logical and strengthened environmental planning and management process and the drawing up of a National Environmental Action Plan for Estonia. The document will address all sectors which use natural resources and pollute or damage the environment, including waste management. The project commenced on 15 April, 1997 and the duration of the project is 12 calendar months.

- PHARE-Programme for Pollution Monitoring and Enforcement, Estonia: 
This is a comprehensive ongoing programme including several components as:

- Master Plan for Pollution Monitoring and Enforcement

- Sampling an Laboratory Equipment Supply

- Improvement of Data Use and Data Management in the Environmental Monitoring System

- Improvement of Enforcement and Monitoring Capabilities: the Environmental Monitoring System

- Supply of a Mobile Unit for Air Emission Monitoring.

All the above components are financed by PHARE through five district contracts.

In addition, the first PHARE project, Master Plan for Pollution Monitoring and Enforcement, has recommended the implementation of a number of other projects (sources of funding not yet identified) such as:

- Institutional strengthening (at the County Level) by hardware supply. The objective is to upgrade the County Environmental Departments for on-site measurements on landfills and on contaminated sites as well as for sampling of groundwater and soil.

- Support of a monitoring programme for operating landfills. The objective of the project is the support of the establishment of a monitoring programme of landfills by preparing the necessary guidelines for technical aspects of monitoring, for reporting and for selection of landfills and by on-the-job-training of staff of national institutions.

- Support of a risk assessment programme for operating landfills. The objective of this project is the support of the establishment of a landfill risk assessment programme by preparing the necessary guidelines and proposals for investigations, for risk assessment, ranking and prioritisation as well as for pre-assessment of re-mediation and improvement measures. A further objective is to train staff members of national institutions or selected members of county administrations within this field of environmental management.

- DESF will be funding a comprehensive two-year project which will focus on Integrated Pollution Control and Prevention (IPPC). The project will assist Estonia in the transposition and implementation of EC legislation on integrated pollution prevention and control.

\section{Principles}

The Estonian Government has decided to focus on the White Paper legislation and is currently emphasising approximation of the White Paper legislation into the Estonian legislation. Due to the present urgent need to establish landfills, approximation of EC requirements for landfills are also given a high priority by Estonian Ministry of the Environment. 
In accordance with the White Paper the immediate needs for implementation into Estonian legislation has been identified. Legislative approximation in the field of waste management presupposes first of all the setting up of a framework for waste management legislation.

Particular attention has to be given to clear definitions (of "waste" and "hazardous waste", "producer of waste", "recovery", "disposal" etc.) in line with EC legislation. Efforts should from the very beginning be focusing also on the implementation of the main principles of the EC legislation and the general requirements in particular in line with the Waste Framework Directive, the Hazardous Waste Directive and the Council Resolution on a Community Strategy for Waste Management.

Main principles in EC waste legislation include:

- Allocation of responsibilities

- Promotion of the hierarchy of waste management

- Preparation of waste management plans

- Establishment of permit system

- Establishment of an integrated network of waste treatment facilities

- Establishment of recording/data/information system(s).

- Polluter pays principle

- Economic instruments

The definitions and the main principles of the white paper legislation should be implemented as soon as possible into the relevant Estonian legislation (primary the Estonian Waste Act, the Packaging Act and possibly the Act on Air Protection, which is under preparation). Furthermore the requirements on landfills should be implemented as soon as possible. It is the intention of the Estonian Ministry of the Environment to introduce the White Paper legislation as well as the draft proposal for a Council Directive on the landfill of waste into the Estonian legislation by the end of 1997 .

Insufficient enforcement and monitoring of some of the existing legislation has been identified by the DEPA project team as a major problem. Severe problems are:

- the lack of lawyers to draft the environmental legislation,

- in general, an insufficient number of employees in the different organisations dealing with waste management, and

- in particular, a lack of technical staff dealing with environmental issues in rural municipalities, as a lot of tasks and responsibility on waste management has been delegated to the municipalities.

The need of institutional strengthening and capacity building at all level (ministry, county and especially local (municipal) level) is obvious, and great attention should be given to the institutional strengthening and the development of a capacity building programme. 
Thus, in addition to the setting up a framework for a waste management legislation, the "practical implementation" to ensure an effective operation of the EC legislation is of paramount importance. The practical implementation includes:

- creation or adoption of the necessary institutions and structures (including facilities, permit system recording etc.), involving fundamental changes in the responsibilities of both the national administrative and juridical systems and the emerging private sector.

- establishment of an administrative infrastructure, including authorities enabled to monitor/supervise waste management activities and enforce the legislation

- promotion of public awareness

It is strongly recommended by the mission to give high priority to capacity building and training of the staff at all level including on the job training on the practical implementation and enforcement of the legislation.

Furthermore it is important to adopt and implement the specific requirements e.g. more stringent requirements for specific waste streams, limit values, targets, inventories, methods of sampling and analysis etc. in an early stage in the process of approximation with EC legislation.

The specific requirements as well as the establishment of an administrative infrastructure and adoption of necessary institutions and structures should be implemented within the next five years along with the EC waste legislation not included in the White Paper.

Finally, the Estonian Ministry of the Environment will be attentive to new proposals for EC waste legislation and to the outcome of the EC working groups in order to consider appropriate implementation into Estonian legislation, when necessary.

\section{WORKING PLAN}

Estonian Ministry of the Environment has prepared the following work programme up to year 2000 for the implementation of EC waste legislation into the Estonian legislation:

\section{7}

- Implementation of definitions, main principles, general requirements and specific requirement of White Paper legislation into the Estonian legislation by the end of 1997. The White Paper includes the following Directives etc.:

- Council Directive 91/156/EEC of 18 March 1991 amending Directive $75 / 442 / E E C$ on Waste (Waste Framework Directive)

- Council Directive 91/689/ 1991 of 12. December 1991 on Hazardous Waste ("Hazardous Waste Directive") 
- Council Decision 94/904/EEC of 22. December 1996 on Establishing a List of Hazardous Waste pursuant to Article 1(4) of Council Directive 91/689/EEC on Hazardous Waste ("List of Hazardous Waste")

- Council Directive 87/101/EEC of 22. December 1986 amending Directive $75 / 439 / E E C$ on the disposal of waste oils ("Waste Oil Directive")

- Council Directive 96/59/EC of 16. September 1996 on the disposal of polychlorinated biphenyl's and polychlorinated terphenyls (PCB/PCT).

- Council Directive 91/157/EEC of 18. March 1991 on Batteries and Accumulators Containing Certain Dangerous Substances

- Commission Directive 93/86/EEC of 4 October 1993 adapting to the technical progress Council Directive 91/157/EEC of 18. March 1991 on Batteries and Accumulators Containing Certain Dangerous Substances

- European Parliament and Council Directive 94/62/EC of 20 December 1994 on packaging and packaging waste (94/62/EC OJ L 365/10. 31 December 1994)

- Council Regulation 259/93 on Shipment of Waste as adapted by Commission Decision 94/721

- Council Directive 86/278/EEC of 12 June 1986 on the Protection of the Environment, and in Particular of the Soil, when Sewage Sludge is used in Agriculture ("Sewage Sludge Directive")

- Implementation of the draft proposal for a Council Directive on the landfill of waste into the Estonian legislation by the end of 1997.

\section{8}

- Implementation of the Council Directive 94/67 /EC on Incineration of Hazardous Waste into the Estonian legislation

\section{0}

- Implementation of EC Directive(s) on incineration of municipal waste into Estonian legislation (New updated EC Directive or Council Directive 89/369/EEC on Prevention of Air Pollution from new Municipal Incineration Plants and Council Directive 89/429/EEC on the Reduction of Air Pollution from Existing Municipal Waste Incineration Plants).

\section{8-2000}

- Implementation of possible new EC Directives or amendments to existing EC Directives in the field of waste management. 


\section{Additional work programme:}

\section{8-1999}

- Institutional strengthening and capacity building of the competent authorities

- Development and implementation of recording/data/information systems in accordance with the national needs and the requirements laid down in EC Directives.

- Planning of the network of future municipal landfills and pre-treatment facilities in Estonia as well as preparation of action plan for recycling of waste in Estonia. The plans will form an input to a national waste management plan for Estonia

- Implementation of permit system(s) in co-operation with a comprehensive two-year project on Integrated Pollution Control and Prevention funded by the DESF.

- Inventory of equipment contaminated by PCB according to the "PCB Directive"

- Development and implementation of new economic instruments in accordance with EC legislation

- Establishment of a separate collection system for batteries in accordance with the "Batteries Directive"

2000-

- Introduction of periodic inspection

- Improvement of monitoring systems

Establishment of an integrated network of waste treatment facilities, raising the public awareness, capacity building of environmental institutions and administrations at all level will as far as possible be carried out stepwise and will be included in the donor supported projects, where possible.

\section{Strengthening of the competent authorities}

As stated the strengthening of the competent authorities at all levels is considered important. Based on the experience from Denmark, it is considered expedient to have the following core staff in the Waste Division of Ministry of the Environment:

- one full time technical expert in the Waste Division of Estonian Ministry of the Environment for each of the main EC directives including the landfill directive

- full time technical experts, each covering 2-3 of the other directives. 
Thus, a future staff of totally 10-12 technical experts in the Waste Division supported by 1-2 lawyers is considered necessary for an efficient implementation and enforcement of the EC waste legislation.

The Chief Inspectors Office should also be strengthened.

Furthermore, it is considered necessary to have one full time technical expert dealing with solid waste management in small counties and towns and possible more in the large counties and towns. In rural and other small municipalities at least one full time technician should be employed with environmental issues. 